\title{
Chapter 1 \\ Global Food Security, Contributions from Sustainable Potato Agri-Food Systems
}

\author{
André Devaux, Jean-Pierre Goffart, Athanasios Petsakos, Peter Kromann, \\ Marcel Gatto, Julius Okello, Victor Suarez, and Guy Hareau
}

\begin{abstract}
In the coming decades, feeding the expanded global population nutritiously and sustainably will require substantial improvements to the global food system worldwide. The main challenge will be to produce more food with the same or fewer resources. Food security has four dimensions: food availability, food access, food use and quality, and food stability. Among several other food sources, the potato crop is one that can help match all these requirements worldwide due to its highly diverse distribution pattern, and its current cultivation and demand, particularly in developing countries with high levels of poverty, hunger, and malnutrition. After an overview of the current situation of global hunger, food security, and agricultural growth, followed by a review of the importance of the potato in the
\end{abstract}

\footnotetext{
A. Devaux $(\bowtie)$

International Potato Center, Quito, Ecuador

e-mail: a.devaux@cgiar.org

J.-P. Goffart

Walloon Agricultural Research Center, Gembloux, Belgium

e-mail: j.goffart@cra.wallonie.be
}

A. Petsakos

Formerly CIP, Seville, Spain

P. Kromann

International Potato Center, Nairobi, Kenya

e-mail: p.kromann@cgiar.org

M. Gatto

International Potato Center, Hanoi, Vietnam

e-mail: m.gatto@cgiar.org

J. Okello

International Potato Center, Kampala, Uganda

e-mail: j.okello@ cgiar.org

V. Suarez · G. Hareau

International Potato Center, Lima, Peru

e-mail: v.suarez@cgiar.org; g.hareau@ cgiar.org 
current global food system and its role played as a food security crop, this chapter analyzes and discusses how potato research and innovation can contribute to sustainable agri-food systems with reference to food security indicators. It concludes with a discussion about the challenges for sustainable potato cropping considering the needs to increase productivity in developing countries while promoting better resource management and optimization.

\subsection{Introduction: The Current Situation of Global Hunger, Food Security, and Agricultural Growth}

A growing earth population and the increasing demand for food is placing unprecedented pressure on agriculture and natural resources. Today's food systems do not provide sufficient nutritious food in an environmentally sustainable way to the world's population (Wu et al. 2018). Around 821 million are undernourished while 1.2 billion are overweight or obese. At the same time, food production, processing, and waste are putting unsustainable pressure on environmental resources. By 2050, a global population of 9.7 billion people will demand $70 \%$ more food than is consumed today (FAO et al. 2018). Feeding this expanded population nutritiously and sustainably will require substantial improvements to the global food system-one that provides livelihoods for farmers as well as nutritious products to consumers while minimizing today's environmental footprint (Foley et al. 2011). A critical challenge is to produce more food with the same or fewer resources.

According to the Global Hunger Index (GHI), substantial progress has been made in terms of hunger reduction for the developing world (Von Grebmer et al. 2017). The GHI ranks countries on a 100-point scale with 0 being the best score (no hunger) and 100 being the worst. Whereas the $2000 \mathrm{GHI}$ score for the developing world was 29.9 , the $2017 \mathrm{GHI}$ score is 21.8 , showing a reduction of $27 \%$. Yet, there are great disparities in hunger at the regional, national, and subnational levels, and progress has been uneven.

Sub-Saharan Africa (SSA) and South Asia (SA) have the highest $2017 \mathrm{GHI}$ scores, at 29.4 and 30.9, respectively. These scores are still on the upper end of the serious category (20.0-34.9), and closer to the alarming category (35.0-49.9) than to the moderate one (10.0-19.9). These data show that persistent and widespread hunger and malnutrition remain a huge challenge in these two regions. In other parts of the developing world within the low range, are also countries with serious or alarming GHI scores, including Tajikistan in Central Asia (CA); Guatemala and Haiti in Latin America and the Caribbean (LAC); and Iraq and Yemen in the Near East and North Africa (NENA) regions. Black et al. (2013) estimate that undernutrition causes almost half of all child deaths globally.

The current rate of progress in food supply will not be enough to eradicate hunger by 2030, and not even by 2050. Despite years of progress, food security is still a serious threat. Conflicts, migration, and climate change are hitting the poorest people the hardest and effectively maintaining parts of the world in continuous crisis. 
The 2017 GHI report emphasizes that hunger and inequality are inextricably linked. Most closely tied to hunger, perhaps, is poverty, the clearest manifestation of societal inequality. Both are rooted in uneven power relations that often are perpetuated and exacerbated by laws, policies, attitudes, and practices.

According to FAO (2002) "Food security exists when all people, at all times, have physical, social and economic access to sufficient, safe and nutritious food to meet their dietary needs and food preferences for an active and healthy life." Food security has four key dimensions: (a) food availability, (b) food access, (c) food quality and use, and (d) food stability.

Food availability refers to the supply of food at the national or regional level which ultimately determines the price of food. Improved availability of food is necessary to reduce food insecurity and hunger but is insufficient to completely end malnutrition, particularly because access to other services such as potable water, sanitation, and health services is also required.

Food access refers to the ability to produce one's own food or buy it, which implies having the purchasing power to do so. Given that a large portion of the poor worldwide are farmers, there remains considerable attention to promoting agriculture to enhance food access. The emphasis on an agricultural pathway to increase food access is twofold, since increased agricultural production provides income to purchase food as well as direct access to food for consumption obtained from own production.

Food use and quality refers to the level of nutrition obtained through food consumption from a nutritional, sanitary, sensory, and sociocultural point of view.

Food stability incorporates the idea of having food access at all times thus incorporating issues such as price stability and securing incomes for vulnerable populations (FAO 2006a).

This widely accepted FAO definition reinforces the multidimensional nature of food security that requires multisector approaches. Such approaches should combine the promotion of broad-based agricultural growth and rural development with programs that directly target the food insecurity as well as social protection programs focused on nutrition including a gender approach (Salazar et al. 2016). Agricultural growth results in rural development and prosperity through a series of multiplier effects, that is, through backward and forward linkages, due to increased incomes. These effects typically stimulate enhanced investment in both farm and non-farm sectors (Hazell and Haggblade 1989; Pandey 2015). Growth in rural farm sector increases demand for goods and services produced by the non-farm sector, further increasing purchasing power and effective demand, thus deepening growth in non-farm sector. Further, Haggblade et al. (2007) argue that the increased income earned in rural non-farm sector can kick off a series of reverse linkages in which such income is invested in agriculture to further strengthen its growth and improve livelihoods of farm households.

During the 2014 World Economic Forum, in a debate on "Rethinking Global Food Security," Shenggen Fan, Director of the IFPRI, argued that tackling hunger and malnutrition is not only a moral issue but also one that makes economic sense. The world loses 2-3\% Gross Domestic Product (GDP) per year because of hunger, 
while investing US\$1 in tackling hunger yields a return of US\$30. Ajay Vir Jakhar, Chairman of Bharat Krishak Samaj (Farmers' Forum) in India, added that farmers do not think in terms of food security at the global level, but in their own households. While policy makers tend to think in terms of global and national issues and solutions, localized solutions and help from the public and private sectors are also needed to support the bulk of farmers who are farming small plots of land and which have a critical role as engines of food productivity growth and social development. By declaring 2014 the International Year of Family Farming, the United Nations acknowledged the importance of family farming in reducing poverty and improving global food security. Localized, technical, and commercial solutions with the support of both public and private sectors are needed in combination with global food security policies.

Therefore, enhancing food security requires policies that improve households' ability to obtain food through production and better income. Growth in agricultural productivity is key to reducing rural poverty since most of the poor depend on agriculture and related activities for their livelihoods. Because the potato is one of the global crops with a most diverse distribution pattern (Haverkort et al. 2014) and is grown in areas with high levels of poverty, hunger, and malnutrition, it can be particularly effective crop for enabling smallholder families to attain food security and climb out of poverty. Hence, innovations based on potato science can be a significant vehicle for targeting the poor and hungry as part of a broader set of research and development activities.

This chapter first presents the importance of the potato in the current global food system and its value as a food security crop. It then discusses the role of agriculture and the potato for their contribution to food security in its different dimensions: analyzing opportunities and challenges on how potato research and innovation can enhance productivity and how potato agri-food systems can contribute to food security at a global scale using natural resources in a sustainable way. A list of key research and technology options that can contribute to sustainable agri-food systems intensification approaches is suggested. The chapter concludes with a discussion about the challenges for sustainable potato cropping combining the needs to increase productivity in developing countries while promoting better input management and optimization. These conclusions emphasize also the need to integrate better agriculture sustainable intensification and food security indicators.

\subsection{The Potato in the Global Food System}

Potato is currently grown on an estimated 19 million hectares of farmland globally, and the potato production worldwide stands at 378 million tons (Table 1.1). The highest concentrations are found in the temperate zone of the northern hemisphere where the crop is grown in summer during the frost-free period. In these regions, potato is mainly grown as a cash crop and is therefore an important source of income. In tropical regions, the crop is significant in the highlands of the Andes, the 


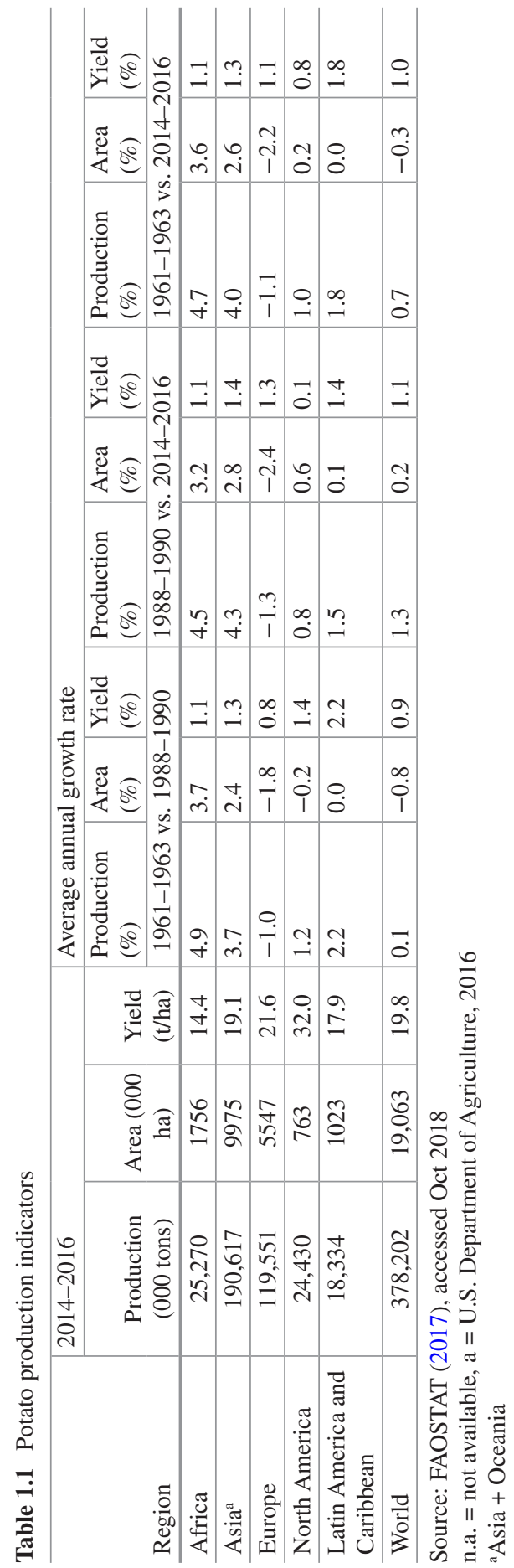


African highlands, and the Rift valley, and the volcanic mountains of West Africa and Southeast Asia, where production is both for food and cash (Muthoni et al. 2010). In the subtropics, the crop is grown as a winter crop during the heat-free period such as in the Mediterranean region, North India, and southern China. It is only in the tropical lowlands that potato is not a main staple, largely because the temperatures in these areas are too high for tuber development and growth in traditional potato cultivars (Haverkort et al. 2014). Figure 1.1 illustrates the current pattern of the potato distribution worldwide (You et al. 2014; FAO 2016).

Potato is now the world's third most important food crop in terms of human consumption, after wheat and rice (FAOSTAT 2013) despite the large proportion of potato produce used for seed and as animal feed (Fig. 1.2). Consumption of fresh potatoes accounts for approximately two-thirds of the harvest, and around 1.3 billion people eat potatoes as a staple food (more than $50 \mathrm{~kg}$ per person per year) including regions of India and China.

\subsection{Potato Production and Demand Trends by Region}

Across global landscapes, the versatility of the potato crop coupled with notable increases in production in many countries over the last two decades is unparalleled, although this increase has been mainly driven by area expansion and secondarily by yield improvements. Global statistics also indicate that potato production is shifting towards developing countries especially with strong increase in production in Asia and Africa, especially in East Africa (Fig. 1.3). In fact, the developing world's potato production exceeded that of the developed world for the first time in 2005

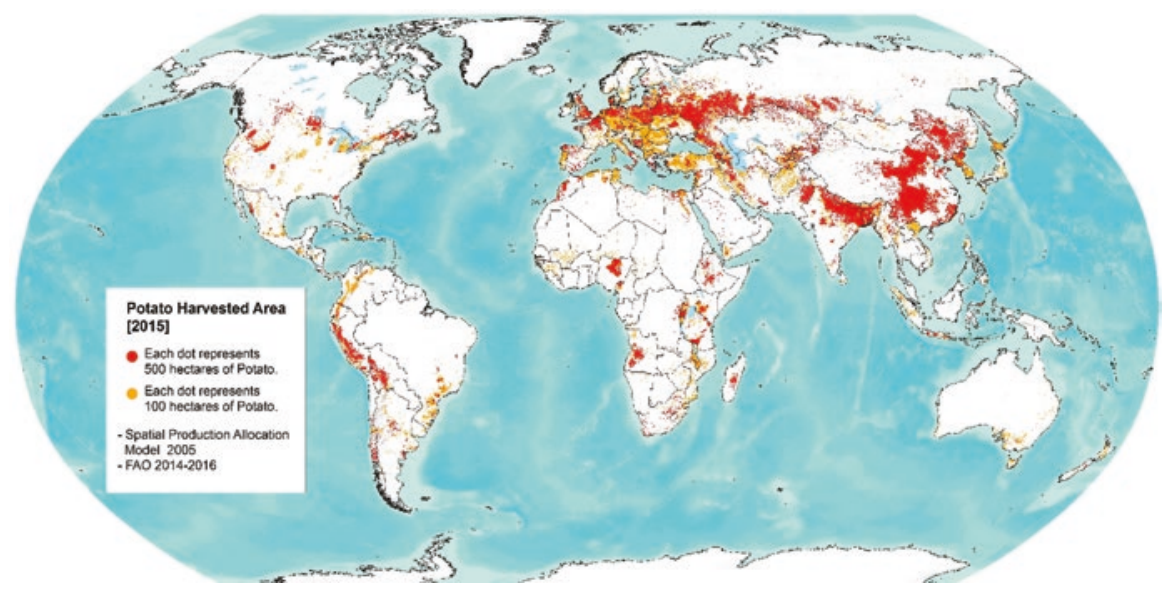

Fig. 1.1 Potato distribution worldwide, harvested area (You et al. 2014; FAOSTAT 2016) 


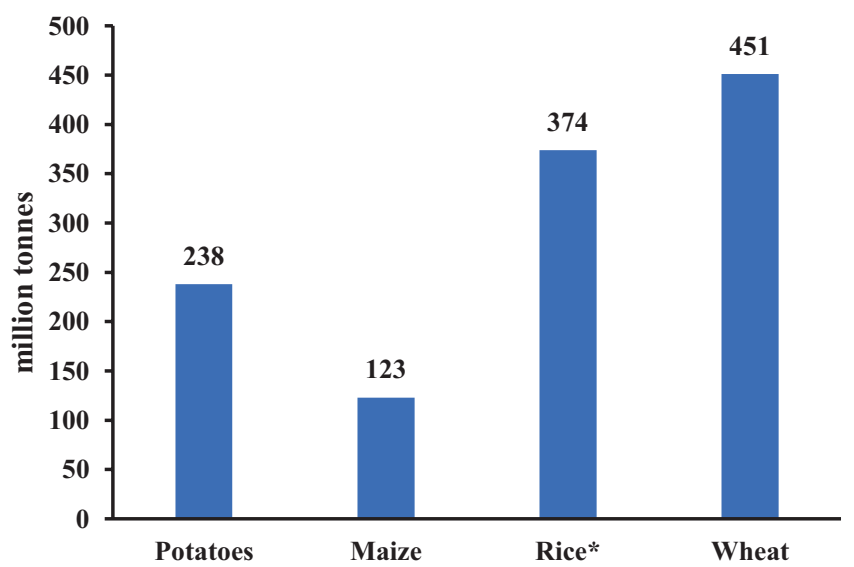

Fig. 1.2 World food consumption per year for the four main nutritious crops. (Source: FAOSTAT 2013)

(a) Global potato production

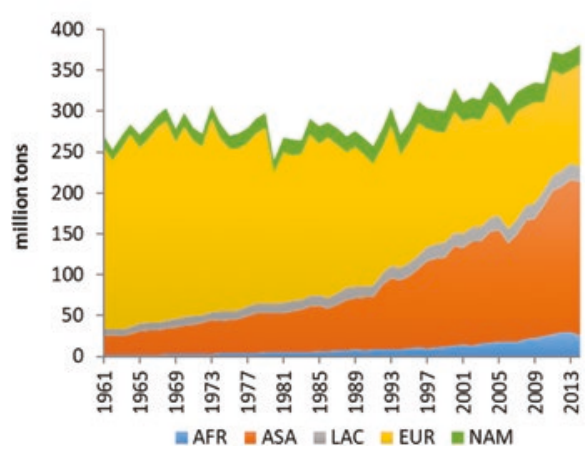

(b) Potato areas harvested

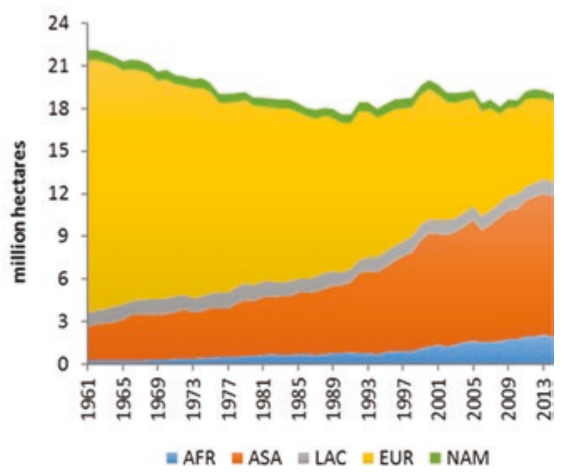

Fig. 1.3 Potato supply (a) and (b) 1961-2013. AFR Africa, ASA Asia, LAC Latin America and Caribbean, EUR Europe, NAM North America. (Source: FAOSTAT 2017, accessed Nov 2017). (a) Global potato production, (b) potato areas harvested

(FAO 2014). It reaffirms the increasing importance of potatoes as a source of food, employment, and income in Asia, Africa, and Latin America.

As shown in Fig. 1.4a, Africa has registered large increases of harvested area over the last 20 years, but despite the impressive growth, total production and harvested areas are still much smaller compared to Europe and Asia (Fig. 1.3a). In Africa, the increase in potato production has largely been through increase of area under production, which more than doubled since 1994 and now exceeds that of the Latin 


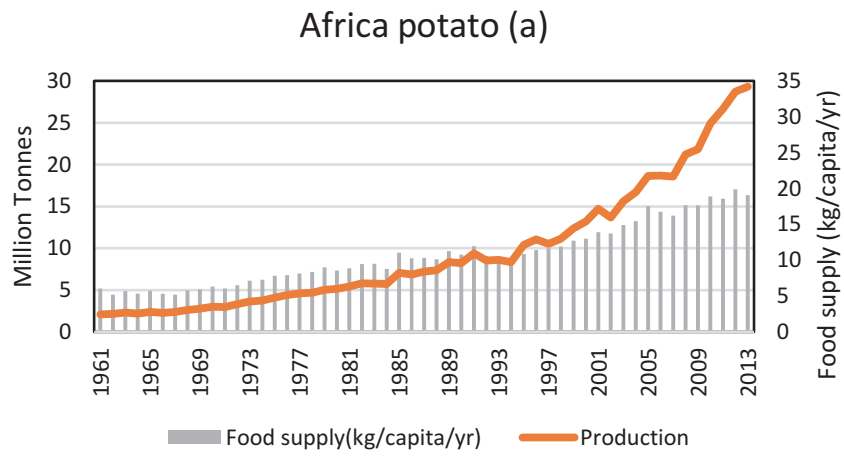

China potato (b)

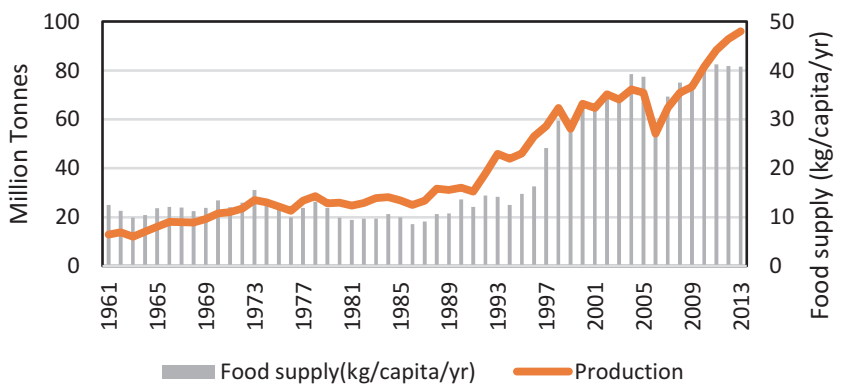

India potato (c)

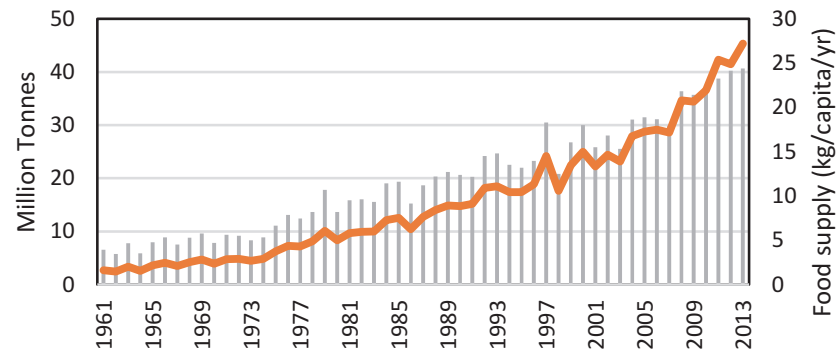

Food supply(kg/capita/yr) Production

Fig. 1.4 Relative development of potato production and food supply $\left(\mathrm{kg} \mathrm{capita}^{-1} \mathrm{year}^{-1}\right)$ in Africa (a) China (b), and India (c). FAOSTAT (2013)

America and Caribbean (LAC) region. In the tropical highlands of East Africa, farmers grow potato both for food and cash (Muthoni et al. 2010). The increase of potato production in East African countries over the last years has been impressive, suggesting a higher contribution of the crop to local food systems. In Tanzania, for instance, potato supply has almost tripled between 2000 and 2014 (FAOSTAT 2017), 
while in Rwanda potato is included in the national priority list of crops due to its role in national food security (approximately $125 \mathrm{~kg}$ per capita consummed per year; FAO 2009). As world population levels are predicted to show the greatest rise in Africa in the coming decades, increased contribution of potato to local food systems in this region is of considerable importance (Birch et al. 2012).

In Asia, China and India have experienced nearly a half century of steady growth in potato production (Fig. 1.4b, c). Both countries also have ambitious growth targets for future years. For some decades now, the Chinese state has been working to increase national potato consumption, also launching a campaign since 2014 to promote both the cultivation and the consumption of this tuber (The Wall Street Journal 2015). China became the world's largest potato producer in 1993 and currently accounts for almost one quarter of global potato production and about $28 \%$ of total cultivated areas (FAO 2015a, b). Potato in China is mainly used for food, both as a vegetable and in processed forms, while a smaller part is also consumed as animal feed (Scott and Suarez 2012a). Potato in India is mainly grown in the Indo-Gangetic plain, either as monoculture or in rotation with maize, wheat, and/or rice and it is regarded as both an important staple and a cash crop. Following the growth in production volumes, potato yields in India have also increased significantly, at an average of $2 \%$ per year, because of successful breeding programs, quality seed systems, and storage infrastructure that have reduced post-harvest losses (Scott and Suarez 2011).

Looking at other Asian countries, potato is the principal vegetable in Bangladesh and the second most important crop behind rice. Its cultivation is widely distributed across the country where it is grown mainly as a cash crop (Scott and Suarez 2012b). Potato production in Bangladesh has greatly expanded during the last decades, especially after 2000 when output surged from about 1.5 million tons to more than 8 million tons in 2013 (FAO 2015a, b). This impressive growth, besides the rising domestic demand because of population growth and the "westernization" of dietary preferences in urban areas (Pingali 2006), can also be attributed to the introduction of several improved high-yielding varieties and the development of cold storage facilities which facilitated near year-round availability of potato. At the same time, producers also gained significant price advantages (Reardon et al. 2012). In Nepal, potato is the second most important staple food crop after rice. The potato has also become a significant source of rural income in Pakistan where production is concentrated in Punjab, with spring and autumn crops accounting for $85 \%$ of the harvest. Expansion of irrigated Pakistani land has resulted in substantial increases in potato production (up 254\% from 1990 to 2009) and area under cultivation.

Regarding potato production in LAC over the past 60 years, the annual average potato domestic supply has increased from 7.2 million tons in the 1961-1963 period to 19.6 million tons in 2011-2013, which represents an average annual growth rate of $2 \%$. By way of comparison, growth rates for potato production in ASA and AFR averaged over $4 \%$ for a similar period, i.e. more than double those of LAC (Scott 2011). Most of the production is oriented towards human consumption (74\%, maintaining this trend throughout the period) and it highlights a relatively low processing level of $1 \%$ (FAOSTAT 2017). 
The role that potato plays in the diets in LAC vary-from basic staple, producer/ consumers in the Andean highlands to complementary vegetable for urban households in most of South America, to a relatively expensive complimentary vegetable in much of Central America and the Caribbean, and to a popular fast food in the form of French fries in urban markets throughout the region (Scott 2011). Per capita consumption of potatoes in Latin America increased slightly from $22 \mathrm{~kg} /$ person on average between 1961 and 1963 to $25 \mathrm{~kg} /$ person between 2011 and 2013. But these regional trends do not reflect the important differences in trends at the subregional and country levels. Peru, is one of the countries where potato consumption has grown significantly, reaching in 2015 a figure of $85 \mathrm{~kg} /$ person. This is due to various public-private policies, rural infrastructure, expansion of supermarket trade focused on potatoes and a strong relationship with the gastronomy sector promoting Andean food including the native potato and its products. Brazil and Mexico have increased their consumption, although their absolute values, 18.5 and $14.8 \mathrm{~kg} /$ person respectively still remain low compared to other countries in LAC. The cases of Argentina and Colombia are showing a downward trend.

The United States is the fifth largest potato producer in the world with more than 420,000 ha harvested in 2013 and a total output of almost 20 million tons (FAO 2015a, b). Although in the United States potato is no longer the traditional staple of the past, it is nevertheless gaining increased appreciation by nutritionists because of its nutrient density and its contribution to a more balanced diet (Bohl and Johnson 2010). There is also a large demand by the processing industry for producing commodities like frozen French fries and chips for both the local and foreign markets. Potato yields in the United States have more than doubled over the last 50 years, rising from 22 tons ha ${ }^{-1}$ in 1961 to 49 tons ha ${ }^{-1}$ in 2016. This increase in yields has been suggested to be primarily driven by improvements in management rather than genetic improvements, since most breeding programs have traditionally focused on quality traits such as dry matter content and storage longevity to meet the demands of the processing industry and the consumer (Douches et al. 1996).

In Europe, Germany, France, Netherlands, the United Kingdom, and Belgium are together the strongest potato producers in the European Union (EU), due to potato yields higher than 40 tons ha ${ }^{-1}$ in this area of northwestern Europe (Fig. 1.5) and to the strong links of production with the dynamic European potato processing industry. Potato is also prevalent in Eastern European countries, particularly in Russia, Ukraine, and Poland where per capita consumption has traditionally exceeded $100 \mathrm{~kg}$ annually. Although Eastern Europe constitutes the region with the highest use of potato as animal feed globally, feed use of potato has been steadily declining over the last 20 years and being replaced by cereals, most notably in Poland. This decline in feed use, together with the shift of diets towards low-calorie food and a trend to spend less time on cooking observed in Western European countries, has led to a significant decrease in demand for fresh potatoes, and therefore potato production in the continent is falling (European Commission 2007). Despite the aforementioned decline, some European countries like France, Denmark, and Belgium have increased production over the last decade, due to growth of the processing industry (French fries, crisps) and starch production (Eurostat 2017). 


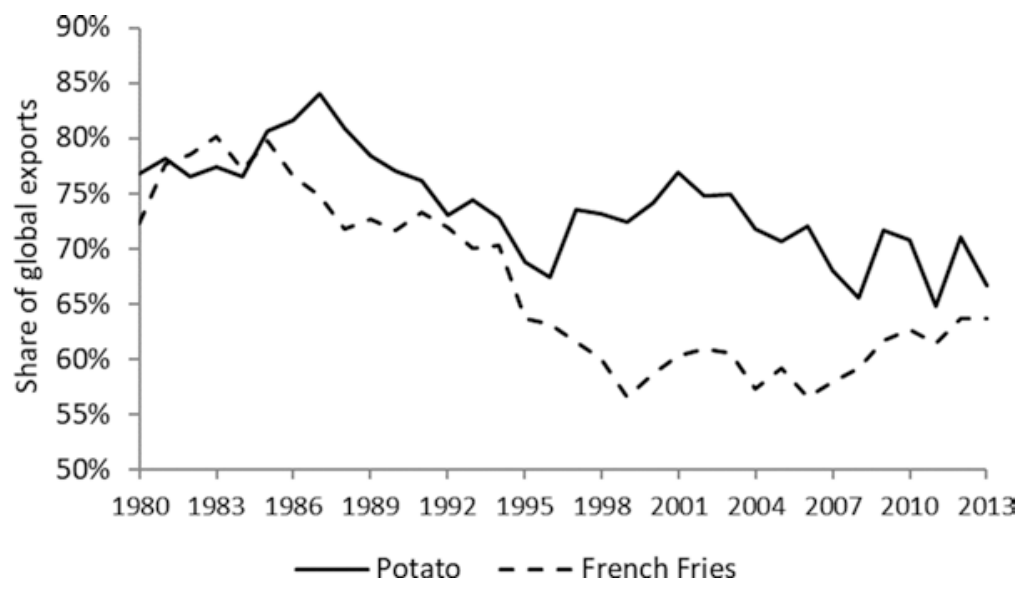

Fig. 1.5 European share of global exports for potato (fresh and seed) and French fries 1980-2013. (Source: FAOSTAT 2017)

Table 1.2 Potato utilization, consumption and trade indicators

\begin{tabular}{|c|c|c|c|c|c|c|c|}
\hline \multirow[b]{3}{*}{ Region } & \multicolumn{4}{|c|}{ Utilization } & \multirow{2}{*}{$\begin{array}{l}\text { Consumption } \\
\text { Per capita } \\
\left(\text { kg year }^{-1}\right)\end{array}$} & \multicolumn{2}{|l|}{ Trade } \\
\hline & \multirow{2}{*}{$\begin{array}{l}\text { Food } \\
(\%)\end{array}$} & \multirow{2}{*}{$\begin{array}{l}\text { Feed } \\
(\%)\end{array}$} & \multirow{2}{*}{$\begin{array}{l}\text { Seed } \\
(\%)\end{array}$} & \multirow{2}{*}{$\begin{array}{l}\text { Other } \\
(\%)\end{array}$} & & $\begin{array}{l}\text { Import } \\
\text { Quantity } \\
\text { (000 tons) }\end{array}$ & $\begin{array}{l}\text { Export } \\
\text { Quantity } \\
\text { (000 tons) }\end{array}$ \\
\hline & & & & & 2011-2013 & \multicolumn{2}{|l|}{ 2011-2013 } \\
\hline Africa & 69 & 4 & 8 & 19 & 19.2 & 967 & 830 \\
\hline Asia $^{a}$ & 67 & 12 & 5 & 11 & 29.1 & 6,042 & 2,683 \\
\hline Europe & 52 & 19 & 15 & 11 & 83.4 & 17,890 & 19,477 \\
\hline North America & 84 & 1 & 6 & 9 & 55.3 & 3,615 & 5,354 \\
\hline $\begin{array}{l}\text { Latin America } \\
\text { and Caribbean }\end{array}$ & 73 & 2 & 8 & 16 & 23.8 & 2,040 & 439 \\
\hline World & 64 & 12 & 9 & 12 & 34.4 & 30,554 & 28,784 \\
\hline
\end{tabular}

Source: FAOSTAT (2017), accessed Oct 2018

n.a. $=$ not available, $\mathrm{a}=$ U.S. Department of Agriculture, 2016

${ }^{\mathrm{a} A s i a}+$ Oceania

Moreover, the competitiveness of the potato industry has established Europe as the world's biggest net potato exporter, amounting for more than $60 \%$ of all exports of fresh potato and a similar percentage of global exports of French fries (Fig. 1.5). These statistics concern mainly intra-EU trade, and also export of seed potato to non-EU countries, primarily to Mediterranean African countries like Egypt and Algeria (FAOSTAT 2017).

Tables 1.1 and 1.2 give a synthesis of the potato indicators by region confirming the expansion of potato in Asia, which is now the major potato producer continent. In Africa, the potato growth rate has also been strong with Egypt, Malawi, South Africa, Algeria, and Morocco producing more than two-thirds of all the potatoes in the region. In many countries of Latin America and the Caribbean, potato areas have 


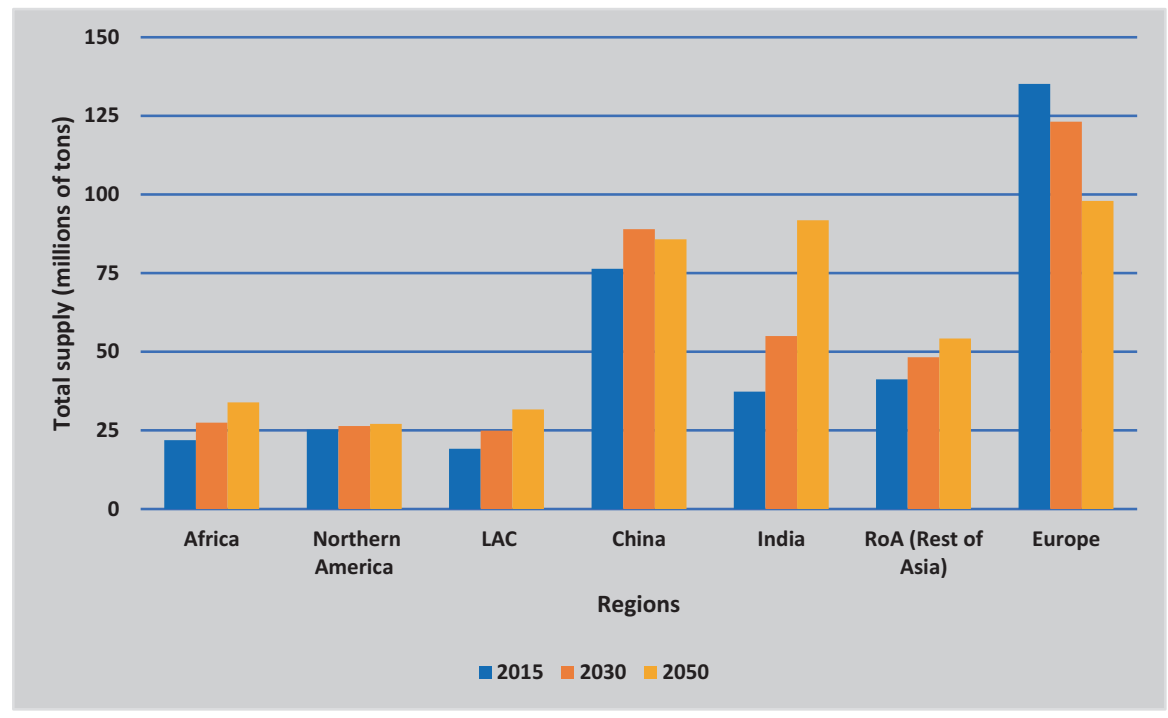

Fig. 1.6 The future of potato production. Adapted from Rosegrant et al. (2017)

declined although output has risen due to improvements in productivity. Potato production growth rate in Europe and North America has declined due to a significant decrease in demand for fresh potatoes that was partially compensated by a large demand from the processing industry as described before. In North America, yields increased rapidly between 1961 and 1990 and then somehow stagnated, suggesting yields are near their potential in the region and there may exist genetic limits. In Europe, on the contrary, the relative larger yields growth rates occurred after 1990.

Future trends by region indicate a major production increase in Asia and Africa as compared to other regions (Fig. 1.6). Considering some underlying assumptions such as population growth, climate change, and economic growth pathways, the UN projects a population decline in China and growth of per capita GDP which will affect diet composition. Therefore, the future supply of potato in China will not continue to grow faster than in the past. According to Rosegrant et al. (2017), it is in India where potato supply will almost triple because of the very high population growth, especially under certain socioeconomic scenarios.

\subsection{The Potato Remains a Food Security Crop in the Developing World's "Nutrition Transition"}

In many developing countries, and especially in urban areas, the globalization, the emergence of fast food outlets and supermarkets and the rising levels of income are driving a "nutrition transition" led by major shifts in the availability, affordability, and acceptability of different types of food, especially toward more energy-dense 
foods and prepared food products. It is translated into major and rapid shifts in dietary patterns. As an example of this nutrition transition process, demand for potato is increasing in many developing countries in Africa and Asia (Fig. 1.3). In South Africa, potato consumption has been growing in urban areas as part of the staple food consumption of the middle class, although maize remains the primary staple in rural areas. In China, higher income and increased urbanization have led to increased demand for processed potatoes. In this context, potato plays a role in diet diversification in many countries where family agriculture and smallholders continue to supply local markets with fresh and affordable agricultural produce. Potato is still an important staple in rural food systems where it is produced, and emerging food systems which are urbanized but where consumers still rely on staples such as potatoes. In Industrial food systems, highly urbanized in Northern countries in Europe and North America with the development of the processing industry there is a lower dependence on traditional staples (Gillespie and Van den Bold 2017).

As mentioned by Haverkort and Struik (2015) potato used to be a "local for local" crop and it still is in many countries because of the bulkiness and the limited storability of the seed and ware tubers. Compared to other staples, and except for processed potato products, fresh potato is a thinly traded commodity in global markets and is absent in major international commodity exchanges. It is therefore subject to less price volatility at global scale. Thus, potato can be relied upon to smooth the disruptions in global food supply and demand that have an impact on other commodity prices, such as witnessed during the 2007-2008 and subsequent food price spikes (FAO 2009).

Potato also improves food security because it is a source of employment and income, both of which have direct links to household food access and nutrition (Pinstrup-Andersen 2014; Kanter et al. 2015). The comparatively short maturity period, nutritious characteristics, employment, and income opportunity that characterize potato make it a resilient crop that can secure vulnerable livelihoods under the effects of climate change and changing market environments. Moreover, potato yields more food more rapidly on less land than any other major crop.

Where other staple crops are available to meet energy requirements, potato should not replace them but rather supplement the diet with its vitamins and mineral content and high-quality protein. Potato can be promoted as a healthy and versatile component of a nutritious and balanced diet including other vegetables and whole grain foods. Likewise, it contributes to combat micronutrient deficiency, also referred to as hidden hunger, which is a major global public health problem, affecting an estimated two billion people globally (Bailey et al. 2015). Potato contains interesting amount of health promoting components such as vitamin $\mathrm{C}$, phenolic compounds, and iron and has protein content comparable to that of cereal grains (Burlingame et al. 2009). When eaten with its skin, a single medium-sized potato of $150 \mathrm{~g}$ provides nearly half the daily adult requirement $(100 \mathrm{mg})$ of vitamin C. It is also a good source of vitamins $\mathrm{B}_{1}, \mathrm{~B}_{3}$, and $\mathrm{B}_{6}$; minerals such as iron, potassium, phosphorus, and magnesium; and contains folate, pantothenic acid, and riboflavin. Vitamin B deficiency has both short- and long-term impacts, including poor cognitive and pregnancy outcomes and poor child development and life outcomes. Vitamin C, 
on the other hand, is important for body metabolism and iron absorption (FAO 2009).

As an example, potato plays an important role in the food basket of most Peruvians; it continues to make up a relatively high proportion of daily calorie availability, reflecting its importance as traditional source of energy. To enhance the nutritional contribution of the potato in rural Andean highlands, the International Potato Center (CIP) coordinated activities to promote innovation in potato-based systems with the objective of contributing to food and nutrition security of rural highland populations enhancing native potato production and promoting dietary diversity. In rural areas of Peruvian highlands, there is a high prevalence of chronic malnutrition amongst children ( $42 \%$ in children under 2 years according to INEI Peru 2017). Native potato varieties are commonly grown in the Andes and are a significant part of the local diets. Some of them have higher contents of micronutrients ( $\mathrm{Zn}$ and $\mathrm{Fe}$ ) and are rich in antioxidants compared to commercial improved varieties. Creed-Kanashiro et al. (2015) explored the relationships between agricultural production characteristics and nutritional status of young children of families in rural areas of Peru whose livelihood is based on potato production systems combining native and commercial varieties. The results showed a positive relationship between percentage of recommended dietary intake (RDI) for both $\mathrm{Fe}$ and $\mathrm{Zn}$ intakes by children and production of native potatoes for home consumption, raising small animals for consumption and sale (e.g., guinea pigs and poultry) and the area of production of commercial potatoes that allowed the families to improve their incomes and diversifying the family diet.

Finally, it should be mentioned that potatoes have been related to increased risks of obesity mainly because of their high glycemic index. Recent reviews of clinical intervention and observational studies centered on the potato concluded that these studies did not provide convincing evidence to suggest an association between intake of potato and risks of obesity, Type II diabetes (T2D), or cardiovascular disease (CVD) (Borch et al. 2016). However, as part of the trend towards urbanization and associated lifestyles, raising incomes, and greater consumption of "convenience foods", demand for fried potatoes is increasing. Overconsumption of these highenergy products, along with reduced physical activity, can lead to overweight and obesity. Therefore, the role of fried potato products in the diet must be taken into consideration in efforts to prevent overweight and diet related noncommunicable diseases, including heart disease and diabetes. For these reasons, even though the potato is a nutritious staple crop, it has often been associated to a meal component with no specific attributes in many societies, even in developing countries. This image is reinforced by some negative myths such that potato is fattening, requires intense use of fertilizers and pesticides for its cultivation and can contribute to soil erosion. Negative images can be mitigated with better information about the nutritional value of the potato and its importance in the diet, while promoting sustainable and environmentally friendly production systems, thus addressing the question of natural resource management. 


\subsection{Policies and Strategies for the Development of the Potato as a Food Security Crop}

The role potato can play as a food security crop at national scale has been addressed in some developing countries with different policies, either sectoral and cropspecific or at the macro level. In its quest to improve food security for a rising population, the Government of China is developing a national plan to increase production and consumption of potato and promoting the crop as a staple instead of a vegetable. This status can give access to important complementary policies and resources at national and regional level and to subsidies from the central government. It also recognizes the double role of potato in current China. Potato is still a major staple for poor rural areas where local governments continue to provide subsidized inputs (e.g., clean seeds of selected varieties), while at the same time being at the forefront of an increasing private sector-led processing industry, accompanying rising incomes in urban populations and diversification of diets (Scott and Suarez 2012a, c).

In Peru, the major center of origin of the potato, a large effort began in early 2000s to develop a competitive and inclusive native potato value chain for domestic markets. Initially led by the International Potato Center, the initiative gathered several private and not-for-profit actors to add value to the native potato grown by small farmers while developing a niche market. Several new products were developed in the process, for example selected native potato varieties for fresh consumption sold as gourmet potatoes in innovative packages in large supermarket chains, snacks such as colored native potato chips, and culinary innovations in the gastronomy sector featuring native potato as a central component of sophisticated dishes. The innovations in the value chain continued and a second round of new products emerged, including for example frozen native potato fries, native potato-based liquors, and even cosmetics made from potato. Although no specific sectoral policies were behind this initiative, the development of the native potato value chain took advantage of Government policies at the macro level promoting private sector and marketled developments and the fast growth of Peru's economy and of the purchasing power of the population since the beginning of the twenty-first century. While the Government of Peru focused on public investments to promote export-oriented agricultural growth, the experience with the native potato value chain has proven successful to link small potato farmers to domestic markets and to develop a more inclusive growth strategy of the highly diverse agricultural sector of the country (World Bank 2017).

A final example of policies that have been adopted to promote the potato sector in developing countries is through seed laws and regulations. Seeds are an important input of production of the potato crop and can affect yields since they are vehicle for important diseases. Seed degeneration due to viruses is one of the most common constraints affecting potato productivity, and therefore large research and extension efforts are made to improve availability and access to quality seeds for small farmers. One particular aspect of potato seed is that it is vegetatively propagated. In most 
developing countries, however, seed systems were first established following developed country standards for cereals and grains, promoting the use of certified seed under a formal seed system. This has led to very low use (less than 10\%) of certified potato seed in most developing countries. To increase access to quality seed by small farmers, the Food and Agriculture Organization (FAO) of the United Nations promoted the definition of a new seed category, the Quality Declared Seed (QDS), that relaxes some of the standards required for Certified Seeds and recognizes the importance of seed producers in providing seed of enough quality through the informal seed system (FAO 2006b). Ethiopia adopted the QDS definition in a new seed law passed in 2016 without distinction of crops. Peru (in 2018) and Ecuador (in 2013) have modified the seed regulation for potato to accept the use of QDS. However, differences still exist on how countries are beginning to adopt this category. While in Peru, the new regulation defines the category as QDS similar to the FAO definition, in Ecuador the regulation defines the new category as "common seed" and introduces aspects of the FAO definition for QDS.

Other countries are updating the regulations regarding seed quality assurance systems for potato to increase availability and access of quality seed by farmers. A broad range of changes are proposed, from relaxing some of the standards required for certified seed to allowing the use of private inspection services to increase the number of seed producers that can be inspected each season (e.g., Kenya). One of the motivations of these changes is the increasing recognition of the role of the potato crop for national food security. Some concerns have been raised, however, on the potential consequences of relaxing seed quality standards on the incidence of seed-borne diseases (e.g., Ralstonia solanacearum).

\subsection{Food Security Challenges and Perspectives for Potato Research and Development}

\subsubsection{Potato in a Global Food Security Context}

The potato, because of its adaptability, its yielding capacity and its nutrition contribution, and as an important component of diversified cropping systems, has a long history of helping relieve food insecurities, and contributing to improve household incomes in times of crisis and today's population expansion. Among important issues and challenges at global level, the European Association for Potato Research (EAPR) Conference in 2017 identified three broad concerns: (1) food security and food safety for a growing population considering consumer's needs; (2) sustainable and environmentally friendly production addressing the question of natural resource management taking advantage of new technologies available such as breeding techniques, biocontrol and big data management; (3) innovation in practice turning scientific results into products and processes to improve the performance of agri-food systems (Andrivon 2017). 
Potato's support to food availability can be achieved through improved productivity, either by increasing yields or expanding production areas, combined with technologies that reduce post-harvest losses. Newly developed potato technologies and production concepts can potentially help create solutions in areas where there is a huge need to increase food production. Figure 1.7 shows the global distribution of yields and the low yield levels in most of the developing world, where observed actual yield is usually much lower than the attainable yield. The actual yield is the expression of a potato cultivar in a specific agro-ecological environment and depends on availability of inputs, the economically optimal use of available inputs given the farmers' conditions, and externalities such as local meteorological variations and climate change as well as the technology level and the quality of crop management. Actual yields range from below 5 tons of fresh tubers ha ${ }^{-1}$ (median yield in Uganda: Gildemacher et al. 2009) to well above 100 tons fresh tubers ha ${ }^{-1}$ (in Columbian Basin, USA: Kunkel and Campbell 1987).

The yield gap, expressed as the difference between actual yield in farmers' fields and the attainable yield — using best agricultural practices—leaves a great potential for improvement considering that, in developing countries, the full expression of the crop's yielding capacity has not yet been achieved. Much improvement is needed in agronomic practices, quality seed production, and varieties tolerant/resistant to abiotic and biotic threats (Birch et al. 2012). The high nutritional value of potato mentioned above reinforces the potential of potato to respond to food security challenges.

To reach impact on food availability, access and better use in diets, proper selection of target areas for potato research and identification of the most important constraints to potato production are crucial for defining priority interventions. As a step towards achieving this and to prioritize options for potato research, CIP led an expert survey to assess priorities for potato research across the developing world (Kleinwechter et al. 2014), and an ex-ante evaluation of the economic relevance of

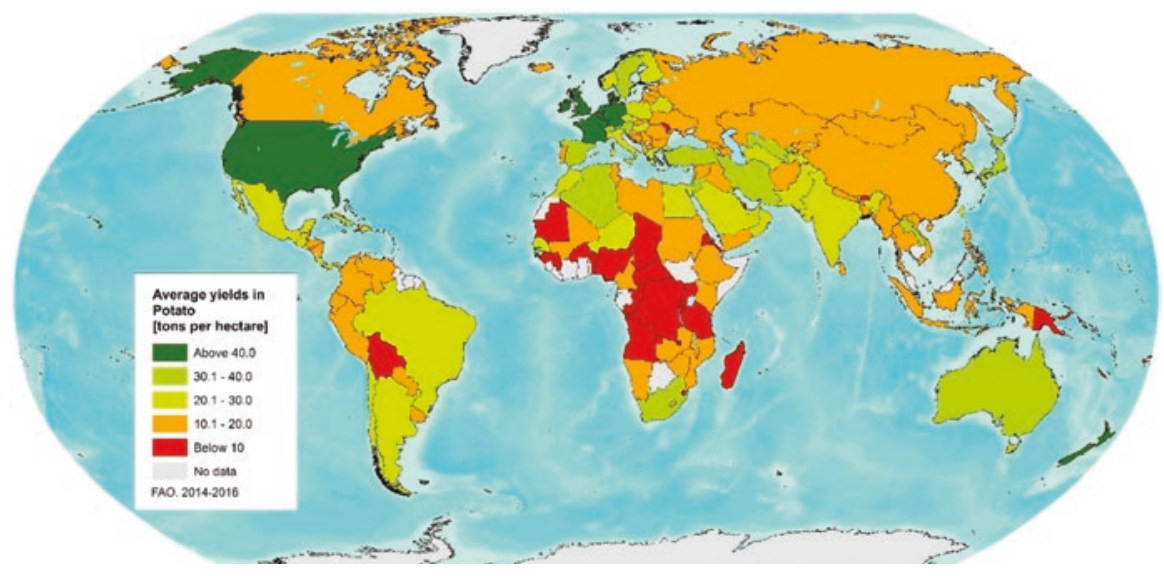

Fig. 1.7 Global distribution of potato yields (tons ha ${ }^{-1}$ ). FAOSTAT, 2014-2016 
these options (Hareau et al. 2014). Most of these research options for potato have been defined to be relevant in numerous countries of Asia, Africa, and LAC. They include research in potato late blight, drought tolerance/water use efficiency, seed systems and development of farmer organizations and farmers' links to markets (e.g., Harahagazwe et al. 2018 for research priorities in Africa). However, the current and upcoming contextual changes, especially considering the climate change requires to revisit some of these issues with a new perspective. Many simulation exercises based on IPCC (Inter-governmental Panel on Climate Change) scenarios and biology models are underway and suggest that future potato cropping systems could differ from those we know today with the implication that new cultivars will be required to respond these new conditions (Andrivon 2017; Quiroz et al. 2018).

\subsubsection{Research and Innovation for Sustainable Potato Cropping}

As suggested by Haverkort and Struik (2015), the future prospects of food security challenges for agricultural production can be expressed by the formula: $\mathrm{P}=\mathrm{G} \times \mathrm{E} \times \mathrm{M} \times \mathrm{S}$ where Performance $(\mathrm{P})$ is determined by Genotype or varieties $(\mathrm{G})$, the Environment or agro-ecological conditions where the crop is grown (E)which as mentioned above is evolving and will further change in the future-its Management and adaptation to local socioeconomic conditions (M) and the Societal requirements $(S)$ driven by society's demands for food and the need to make agriculture more environmentally and consumer friendly with a focus on food safety. The societal or consumer requirements will vary according to the context. In highincome countries, consumers are looking principally for healthy and easy to prepare foods while in the developing world, the consumers' needs are driven by the food and nutrition challenges and demand concerns principally food availability in both quantity and quality. The actual performance of potato can be expressed as yield of fresh or dry matter per unit area or yield of the finished product per unit area recovered from the raw material after processing.

This Performance analysis $(\mathrm{P}=\mathrm{G} \times \mathrm{E} \times \mathrm{M} \times \mathrm{S})$, suggested originally in the context of high-income countries, can be used for the developing world considering the need in most countries to principally respond to the hunger and malnutrition problems through a more efficient agri-food system but based on family agriculture. Family farms are the backbone of agriculture in low- and middle-income countries in Africa, Asia, and Latin America. For many years, the trend in the developed world has been towards intensification to achieve more outputs per unit of land but the sustainability of this intensification is under debate especially considering agriculture's ecological footprint. In low-income countries, sustainable intensification (SI) is a different challenge because it starts from a much lower level of inputs than in developed countries. This is especially the case in Africa where potential for increasing production through area expansion is diminishing, partly due to high 
population growth (Headey and Jayne 2014). For instance, Wu et al. (2018) and Jayne et al. (2014) argue that even though Africa has a high cropping intensity gap ${ }^{1}$, closing this gap sustainably must focus on input intensification rather than area expansion. The relevant question is how to promote technology options that allow for increased output quantity and quality (especially from the nutrition point of view), while considering agriculture's environmental impact, preserving land and other resources in both developed and developing countries. In this context, sustainable intensification of potato cropping goes beyond production aspects and considers strong socioeconomic, demographic, and environmental trade-offs to optimize performance. Institutional incentives to support innovation involving diverse stakeholders, with emphasis on research partnerships, are also required to respond to hard-to-find compromises that will vary between different cropping systems (Hall et al. 2001). Multidisciplinary approaches contribute to recognize and solve practical problems at the level of the crop, the cropping system and the agri-food system to achieve sustainable food security in its four dimensions.

The issues mentioned above indicate that sustainable potato production and efficient use of resources will require future adjustments and redesigns of the cropping and processing systems. Two main options can be considered to increase food security, which remains a main goal for future potato research: (1) produce more with less through better input management and optimization; (2) to produce just as much but waste less both before and after harvest through better value chain management, better storage, processing and marketing operations, and responding to increased involvement and awareness of consumers (Andrivon 2017).

As an attempt to analyze how to combine and score different research and technology options according to their effect on sustainable agri-food system indicators in developing countries and their relation to the four dimensions of food security, Table 1.3 attached suggests a list of priority research and technology options in the spheres of G and M. The assessment is based on the literature and the authors' expert opinions. We scored key options using some critical indicators of sustainable agri-food system intensification related to productivity, agriculture income, human well-being and environmental sustainability according to Smith et al. (2017). We scored the research and development options using a simple scale of high, medium, and low effects according to their relation to sustainable intensification indicators and their main contribution to one of the four dimensions of food security.

The performance of any of these technologies or development approaches will, as expressed by the Performance equation $(\mathrm{P}=\mathrm{G} \times \mathrm{E} \times \mathrm{M} \times \mathrm{S})$, depend on external factors both socio economic and agro-ecological. Their potential contribution to food security will be strongly influenced by the environment (E) and the societal (S) requirements in the local context where they are implemented-e.g., enabling environment, policies for financial and nonfinancial services are also key components for achieving efficient food systems.

\footnotetext{
${ }^{1} \mathrm{Wu}$ et al. (2018, p. 2) define cropping intensity gap as "the amount of incremental cropping intensity that is possibly available if all croplands in a given region are fully intensively used."
} 
A. Devaux et al.

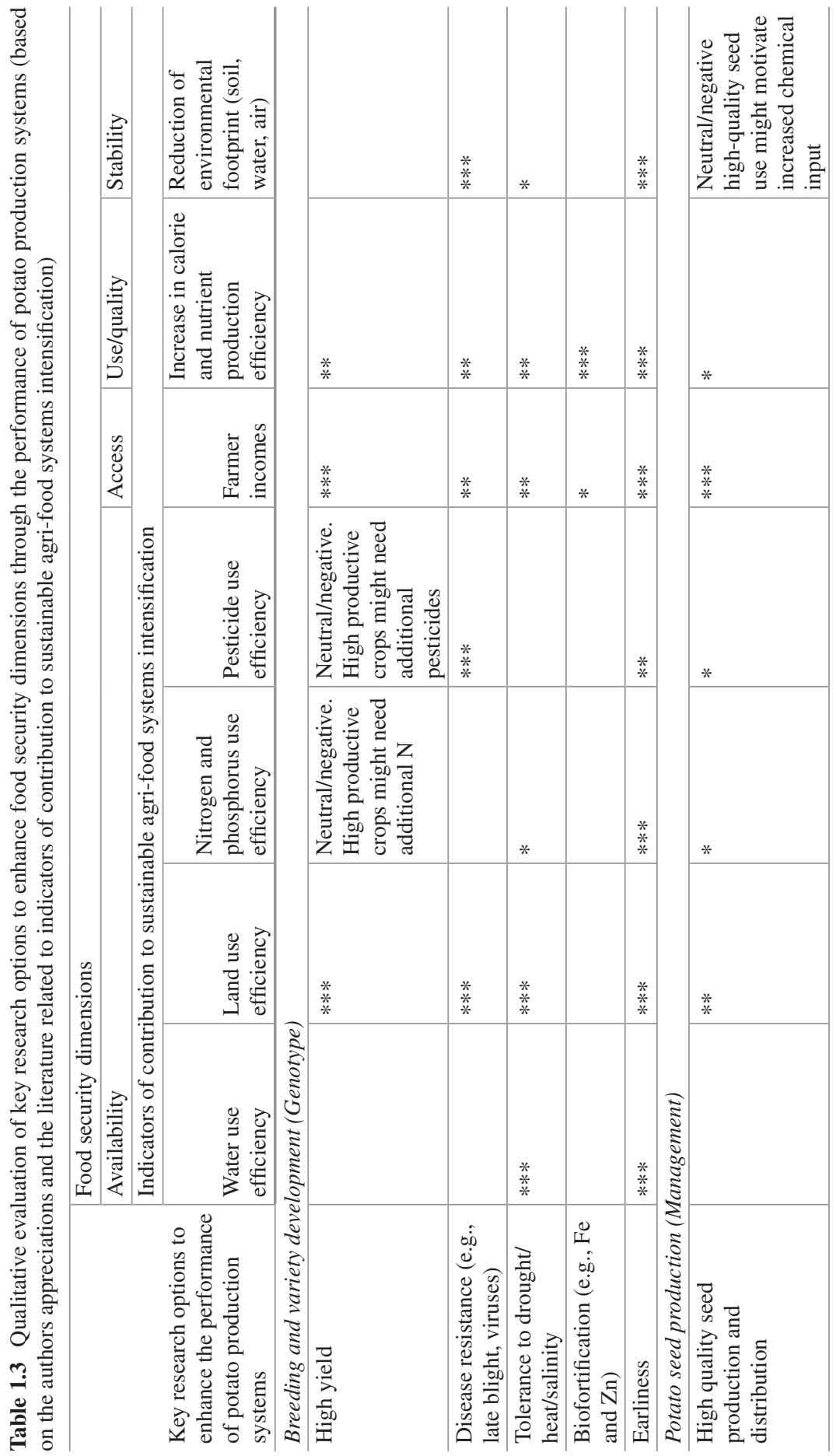




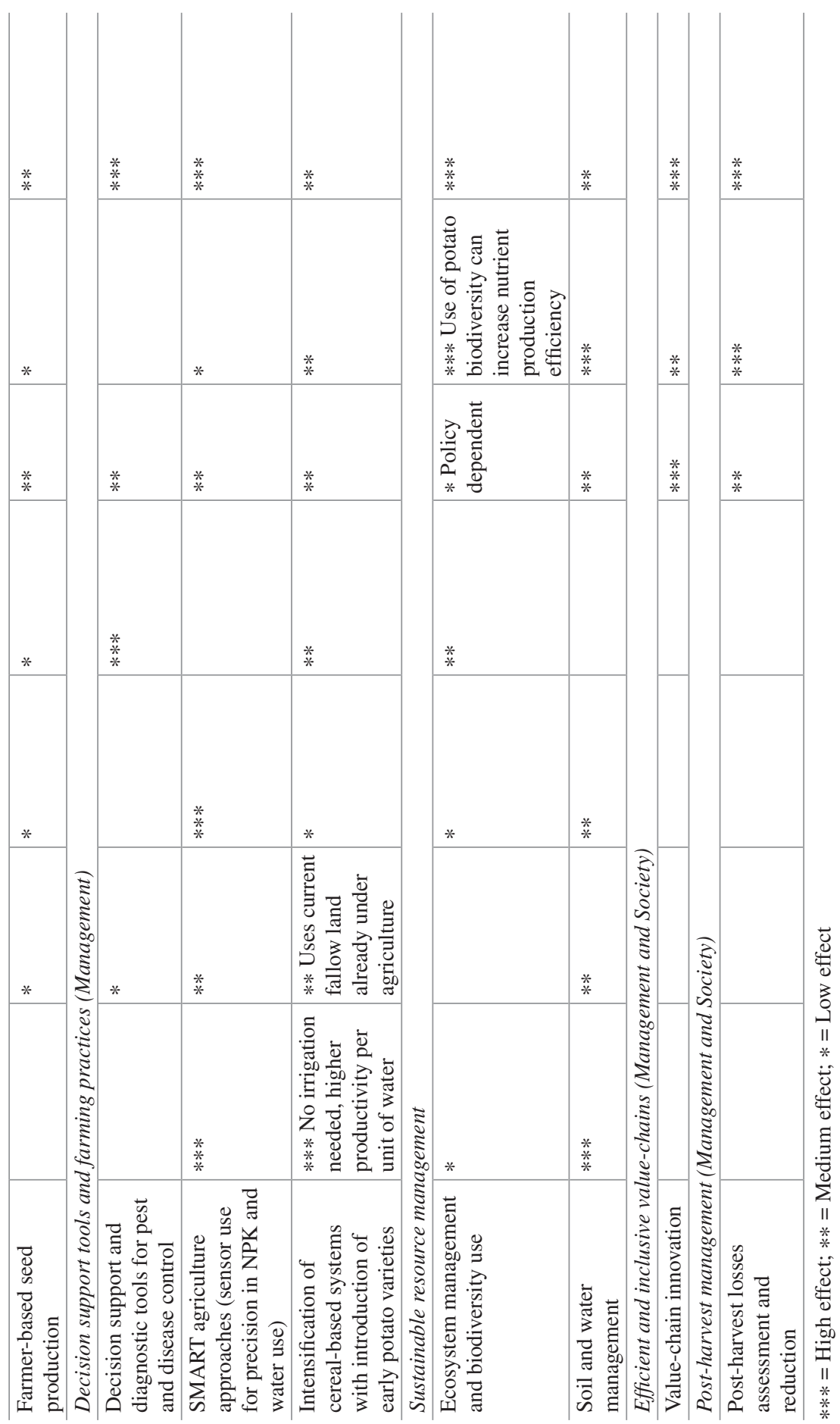


In the sections below, some key research and technology options identified in Table 1.3 are briefly described.

\subsubsection{Potato Breeding, a Driving Force Towards More Efficient Potato Production}

For genotype development $(\mathrm{G})$, priority should be given to achieve a combination of traits to enhance stress tolerance and nutritional aspects to better respond to contextual changes, especially climate and local needs. The recent development of participatory breeding helps to best define the crucial trait combinations required and to facilitate acceptance of new genotypes by growers (Schulte-Geldermann et al. 2012). With the recent findings on the potato genome sequence (PGSC 2011) and the possibilities occurring with new breeding technologies (NBTs), potato breeding appears as the number one opportunity to improve potato production for global food security (Birch et al. 2012).

In many developing and in-transition countries governments have substantially invested in breeding improved varieties. A total of about 840 improved varieties $^{2}$ with various combination of traits have been released, most of which in Asian countries like China and India (Table 1.4). CIP has considerably contributed to global crop improvement through supporting NARS and providing access to advanced breeding material. About $43 \%$ of total releases are CIP-related (i.e., NARS-bred varieties distributed/facilitated by CIP, NARS selection from CIP crosses, NARS crosses from CIP progenitors). At the regional level, CIP-related varieties are most prominent in Africa where $70 \%$ of total releases are CIP-related. This points to the importance of CIP in the regions and the support many national breeding programs require.

Table 1.4 Total and CIP-related number of releases by region

\begin{tabular}{l|l|l|l|l}
\hline Region & Year & Total & CIP-related \\
\hline Asia $^{\mathrm{b}}$ & 2015 & 518 & 180 & $35 \%$ \\
\hline Africa $^{\mathrm{c}}$ & 2010 & 178 & 124 & $70 \%$ \\
\hline Latin America $^{\mathrm{d}}$ & 2007 & 141 & 60 & $43 \%$ \\
\hline Total & & $\mathbf{8 3 7}$ & $\mathbf{3 6 4}$ & $\mathbf{4 3 \%}$ \\
\hline
\end{tabular}

${ }^{a}$ NARS-bred varieties distributed/facilitated by CIP, NARS selection from CIP crosses, NARS crosses from CIP progenitors; calculations for Asia based on Gatto et al. (2018), for Africa on Labarta (2015), for Latin America on Thiele et al. (2008)

${ }^{\mathrm{b} B h u t a n, ~ B a n g l a d e s h, ~ C h i n a, ~ I n d i a, ~ I n d o n e s i a, ~ N e p a l, ~ P a k i s t a n, ~ P h i l i p p i n e s, ~ S r i ~ L a n k a, ~ V i e t n a m ~}$ 'Burundi, D.R. Congo, Ethiopia, Kenya, Madagascar, Malawi, Rwanda, Tanzania, Uganda ${ }^{\mathrm{d} B o l i v i a, ~ C o l o m b i a, ~ E c u a d o r, ~ P e r u, ~ V e n e z u e l a ~}$

\footnotetext{
${ }^{2}$ The current true total number of releases is likely higher given that the most recent data available dates back more than a decade.
} 
(a) Releases with abiotic traits

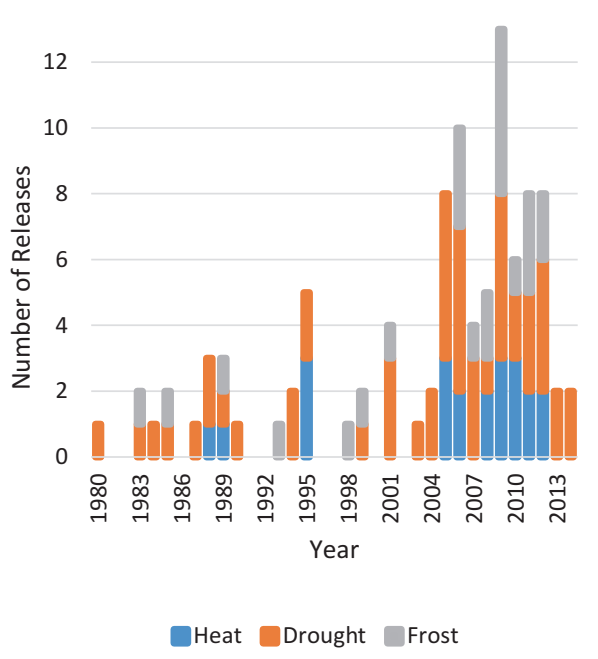

(b) Releases with biotic traits

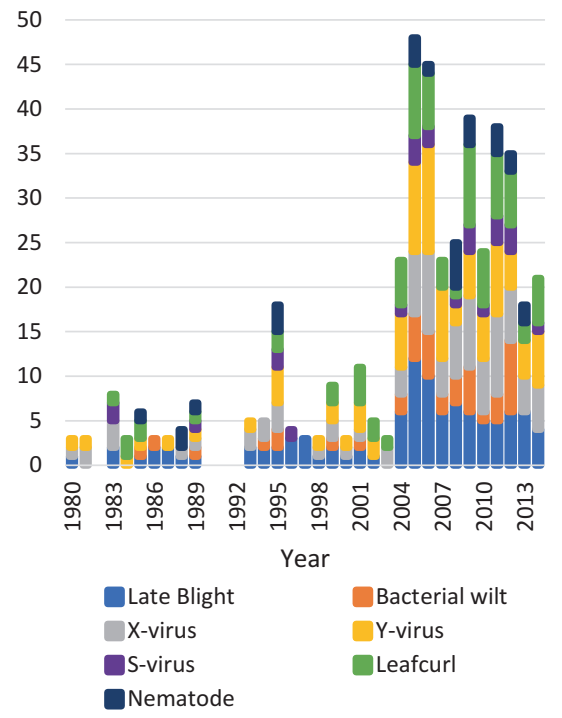

Fig. 1.8 Total releases with abiotic and biotic traits in Asia between 1980 and 2014. Notes: release is for high resistant category only. Medium and low resistant, and susceptible categories are not shown. (Source: Gatto et al. 2018)

The development of early and high-yielding varieties with resistance to $P$. infestans has been a longstanding potato breeding objective. Genotypes with resistance to viruses (PVY, PLRV, PVS, PVX), nematodes (mainly Globodera and Meloidogyne species), bacterial wilt, and a broader spectrum of cultivars tolerant to abiotic stresses like heat, drought, and saline conditions, and focus on beneficial root traits, can increase productivity and expand potato production to new areas.

The importance to develop and release varieties with high tolerance to abiotic stresses and high resistances to biotic stresses has increased, as Fig. 1.8 depicts for Asia. Especially starting in the early 2000, major traits have been bred into released varieties likely as a result of adjusting breeding objectives aiming increasingly at mitigating the adverse effects associated with climate change and variability.

New resilient varieties will potentially expand potato production to new areas and produce more nutritious food under current and future stress factors. Genetic biofortification through conventional and new breeding techniques can help to overcome micronutrient malnutrition and support the consumption of better-quality tubers. This crop improvement approach aims to positively influence human health, as a complement to diet supplementation and food fortification. In recent years, CIP has initiated the development of Fe and $\mathrm{Zn}$ biofortified potatoes, under the umbrella of the HarvestPlus Program (http://www.harvestplus.org/), a global interdisciplinary alliance for developing biofortified varieties of staple crops. Food security programs working to deploy biofortified crops will strongly benefit from nutritional education efforts and awareness programs considering gender roles in the beneficiary communities. 


\subsubsection{Seed Quality and Availability, the Key to Harvest Success}

As sustainable potato production depends on a constantly renewed supply of disease-free planting material, improving quality seed production and seed distribution is another strong avenue of research opportunity related to crop management (M) in potato development. The conceptual framework underpinning the concept of seed security contemplates different types of seed insecurity: poor seed quality, lack of availability, limited access to high quality seed, lack of access to preferred and adapted varieties, inefficient seed systems (FAO 2016; CGIAR/RTB 2016). As a vegetative propagated crop, the growth, development, yield and quality of the potato is strongly influenced by the quality of the seed tubers planted affected by their physical, physiological and health status. More than $90 \%$ of seed potatoes in developing economies is produced in the farmer-based category and is considered to be of poor quality (Thomas-Sharma et al. 2015). Potato seed production systems should support the access to high quality seed potato tubers of improved varieties by combining rapid multiplication technologies (e.g., aeroponics or sand hydroponics) with decentralized seed multiplication, e.g., promotion of quality declared seed systems (FAO 2006b; Fajardo et al. 2010). It should be complemented with on-farm seed maintenance (e.g., positive selection, small seed-plot technique and improved storage) in an integrated approach (Gildemacher et al. 2011; Schulte-Geldermann et al. 2012; Thomas-Sharma et al. 2015; Obura et al. 2016). Improving technologies for farmer-based seed production and distribution of high quality planting material of existing and new varieties have the potential to reach high numbers of beneficiaries with strong impacts on poverty reduction and food availability.

\subsubsection{Potato Crop Management and Farming Practices to Increase Productivity and Sustainability}

The highly adaptable potato can fit to many types of environments (E) from sea level to high mountain conditions where small-scale farmers predominate. Beside temperature regime and solar radiation, there are many factors that affect its productivity as for example, soil characteristics, water use efficiency, nutrient availability and hazards such as night frost or heat waves that may drastically impact resource use, and thereby sustainability. The adaptation of the crop depends on the genotype but also on the crop management practices (M) that need to evolve according to the specific agro-ecological conditions, the socioeconomic context and the local production systems. Crop management is context specific and should consider local knowledge that can be improved promoting new tools and approaches.

Smart agriculture is a novel avenue for resource use optimization based on new monitoring and decision support tools. Remote sensing and global information system (GIS) tools coupled with decision support systems (DSS) and precision agriculture technologies may contribute to increased productivity while interaction among 
biophysical and social disciplines for sustainable food production intensification can at the same time contribute to resource use optimization. Fertilizer (N, P and K) recommendation systems are now using field scale models as well as tractor, drone and satellite embedded spectral sensors to monitor crop nutrient status to supplement fertilization according to inter and within field variability (Goffart et al. 2008, 2017). These more sophisticated technologies are still mainly used in the highincome countries, but massive and varied data management could foster new models to be developed and contribute to decision support systems under developing country conditions. CIP is adapting such system to the Andean condition developing a strategy to manage late blight that combines host resistance and a decision support system to optimize the use of fungicides. The vulnerability of the crop to many pests and diseases, which the current global climate change can worsen, remains one of the most severe threats for a wider potato diffusion and its sustainable cropping. To improve crop health, portable molecular diagnostic tools and decision support systems for early warning and control of pests and diseases (e.g., for efficient fungicide use to control late blight) will contribute to better crop production monitoring and input use efficiency. Research to develop biocontrol is very active and considered to grow substantially in the coming decade, but there are still few confirmed successes from the field, and specific management tools (Decision Support Tools) are still missing (Velivelli et al. 2014). CIP and EAPR are coordinating actions in Europe and Latin America to promote biocontrol and compare the efficiency of biocontrol agents using defined protocols (Devaux et al. 2017).

Specific intensification practices can be developed under specific cropping systems such as in the cereal-based systems in India through "Double-Transplanting (DT)" of rice and planting early maturing potato between the two rice crops as a valid alternative to the traditional potato-boro rice and kharif (monsoon) rice-boro rice. This cropping pattern contributes to enhance system productivity without sacrificing area or productivity of either of the two crops, thus creating new opportunities for potato cultivation for small-scale producers (Arya et al. 2015).

To enhance ecological sustainability, the objective is to implement management practices that increase the level of provision of ecosystem services such as natural soil fertility and biological control. Natural regulation of pests and diseases is an important element in potato agro-ecosystems. In organic farming, it has been demonstrated that the development of natural antagonist associations of the Colorado beetle, such as auxiliary insects and useful pathogens, can significantly improve the control of such a pest for the potato crop (Crowder et al. 2010). Another example of ecosystem management is the delivery of nitrogen through natural fixation and mineralization, which can be enhanced by cropping practices such as cover crops, legume-based intercropping systems and application of organic soil amendments before the potato crop. Biodiversity based agricultural approaches that rely on the design and management of on-farm agrobiodiversity to generate ecosystem services is another avenue to reduce potato's ecological footprint and increase farmer's resilience to cope with frost risks as it is the case in the Andes. The management of ecosystems at field and landscape level can provide a series of production benefits to reduce the need for off-farm inputs. The analysis of beneficial 
microbial communities and their impact on potato plant phenotypes expressions still needs to be developed as discussed at a EAPR-CIP workshop on biostimulant and biocontrol agents (Devaux et al. 2017).

\subsubsection{Integrating Food Security and Value Chain Development}

Although potato remains a staple food in rural areas in developing countries, it is also increasingly becoming a cash food for farmers in Asia, Africa and LAC (DeFauw Sherri et al. 2012). The majority of potato producers are smallholders who depend strongly on agriculture, including the potato crop, for income, food security and employment. Potato production reaches consumers via multilevel marketing systems, not directly from the farmer's field. Thus, the challenge to achieve food and nutrition security as well as prosperity for these smallholders will be obtained or lost by the way agricultural value chains are coordinated. Value chain development and organized markets through farmer associations, storage facilities, and better links with traders and consumers are then required to allow potato producers to access better value markets to get higher and steady incomes from their production. In the recent years, research activities to improve the efficiency of the value chain and coordination among its actors have evolved to achieve more inclusiveness in the value chain development approaches (Devaux et al. 2018). Several factors are contributing to this evolution: changes in consumer demands, new or emerging markets with strict standards, including food safety, processing technologies, and better access to market information. To respond to these changes and the need to make agriculture more environmentally and consumer friendly responding to the Society's requirements $(S)$, research should be characterized by an interaction between natural and social sciences and should be market-driven considering the needs and challenges of all value chain stakeholders. In a compendium about perspectives on the status of innovation for Value Chain Development, Devaux et al. (2016) analyze the opportunities emerging from new markets for agricultural produce and identify challenges to smallholder participation in these markets, approaches for increasing access to markets through strengthening value chain stakeholders' relationships, enhancing innovation and improving an enabling environment. Linked to the value chain efficiency, the assessment of food losses across the value chain and the quality of marketed potatoes also require further research efforts to optimize food availability and consumer access to quality potato products.

\subsubsection{Post-harvest Management: Reducing Food Losses}

As indicated above, another way to face the food security challenge is to produce just as much, but waste less through better post-harvest management. Post-harvest management in potato, including storage, processing and value chain efficiency, is 
a much larger problem than cereals and deserves special attention. Reduction of food losses appears as a key opportunity. The basics of storage management have not changed, but the implementation and application of the basics are evolving worldwide, according to diversity in location, climate and market criteria, that will influence storage management structures and management decisions (Olsen 2014). In developing countries, recent studies have analyzed food loss across the potato value chain, as for example in Ecuador and Peru, by collecting qualitative and quantitative data to provide a comprehensive identification and characterization of losses. The results show that the most important losses occur in the production node, ranging from 90 to $95 \%$ of the total losses in the chain. On average farmers suffer this highest loss across the value chain ranging between 8 and $20 \%$ of their production at or before harvest before moving on to the next node of the chain. The main causes of losses are poor crop and harvest management, infested tubers by pest and diseases, high percentage of small tubers and weather conditions: frost and heavy rains (Delgado et al. 2017).

\subsection{Concluding Remarks: Towards Future Potato Research for Global Food and Nutrition Security}

The analysis of leveraging potato agri-food systems for global food security issues and challenges in this chapter emphasizes the need for making agricultural research programs and food system interventions more responsive to food security dimensions. The multidimensional nature of food security requires multisector innovation in approaches that allow to use the knowledge available and transform scientific results into products and processes to improve the performance of agri-food systems, considering the challenge to produce more food with the same or fewer resources.

In both developed and developing countries, innovations resulting from potato research should be incremental through a step by step improvement of an existing structure promoting technologies adapted to the local context. This is particularly true for smallholder family agriculture in developing countries where there is a great need to increase potato production in a sustainable way. While this approach has the advantage of not destabilizing an existing system, it may also suffer of a systemic lock-in or a lack of enabling environment that keeps agriculture and food systems on less efficient pathways as developed by Baret (2017). An example of lock-in is the use of pesticides and their promotion by agro-chemical companies and technical support services that influence farmers' decision making, restraining the use of more environmental friendly options such as decision support tools for efficient pest control with a more rational pesticide use. The valuable use of varieties tolerant or resistant to pests and diseases can also be limited by processing companies that promote varieties for their processing characteristics regardless of their environmental footprint. In developing countries, low infrastructure quality, weak institutions and policies create also huge limitations to the adoption of new and 
more sustainable technologies. To reach food security goals, a stronger emphasis must be put towards promoting evidence-based policies for communicating information and influence decision makers. It is also important to favor affordable and better-adapted technologies that can respond to the needs of small-scale farmers and, significantly limit negative impacts towards the environment. The research and technology options proposed in this chapter will require policy support, financial and nonfinancial services to have a chance to be adopted and used by local farmers. They will also necessitate a better access to discovery and creative ideas through better services from the potato research community at national and international levels.

Local calibration/validation and demonstration are two essential phases towards local end-user uptake, either involving farmers or extension services representatives. Public or private investments are also required to support such actions to enable farmers to have access to new technologies, and to be trained in their use. With the upcoming of new communication technologies such as smartphones, expansion of mobile broadband and access to local online platforms integrating large amounts of local data and links to Decision Support Systems, we have yet to fully exploit the potential of information technologies especially in developing countries. Local farmers, especially the younger ones, are expected to be able to have increasing access to such new adapted tools, i.e. for Late Blight management in the Andes. But this will only be possible globally if technological innovation is accompanied by capacity building and institutional innovation (associativity, access to credit, communication network) in rural areas.

There is a great dichotomy between research activities in developed versus developing countries that highlights the need for more exchange, knowledge sharing, and collaboration. Since 2014, the interaction between EAPR-linked research organizations and CIP has been looking at mechanisms to enhance partnership between European partners and CIP involving research partners in the Southern hemisphere to promote collaborative research activities, links between research networks such as Euro and Latin Blight (Acuña et al. 2017) as well as facilitating short and long-term training with universities in Europe (Durroux-Malpartida 2014).

To reach the strongest impact on food security, potato research and development efforts need to move towards food systems engineering, rather than focus explicitly on technology/solution development. In this paper, we are analyzing the different components that contribute to the performance of the potato using the key relation $\mathrm{P}=\mathrm{G} \times \mathrm{E} \times \mathrm{M} \times \mathrm{S}$, enabling a list of key research and technology options to guide agriculture research and technology development toward sustainable intensification approaches responding to farmers' needs both for food security and better income. The argument is that agricultural programs need to integrate better agriculture sustainable intensification and food security indicators considering also other dimensions such as quality, diversity of products, health impacts and climate change effects. Multidisciplinary approaches and a better understanding of the evolving food systems are required to recognize and solve practical problems of the whole potato value chain to achieve sustainable food security. Policies, investments and 
services that support agricultural productivity, sustainability and expand risk management capacity are also required to give potato farmers the best chance to meet future needs, while increasing their adaptability and resilience to foster food security.

Acknowledgements The authors are grateful and sincerely appreciate the valuable contributions of Mr. Henry Juarez and Dr. Jorge Andrade-Piedra. Their inputs, opinions, and suggestions have greatly contributed to improve this chapter.

\section{References}

Acuña I, Restrepo S, Lucca F, Andrade-Piedra J (2017) Recent developments: late blight in Latin America. In: Schepers HTAM (ed) Proceedings of the sixteenth EuroBlight Workshop, Aarhus, Denmark, 14-17 May 2017. PAGV special report no. 18

Andrivon D (2017) Potato facing global challenges: how, how much, how well? Potato Res 60:389. https://doi.org/10.1007/s11540-018-9386-z

Arya S, Ahmed M, Bardhan Roy SK, Kadian MS, Quiroz R (2015) Sustainable intensification of potato in rice-based system for increased productivity and income of resource poor farmers in West Bengal, India. Int J Trop Agric. ISSN 0254-8755 33(2):203-208

Bailey RL, West KP Jr, Black RE (2015) The epidemiology of global micronutrient deficiencies. Ann Nutr Metab 66(Suppl 2):22-33

Baret PV (2017) Acceptance of innovation and pathways to transition towards more sustainable food systems. Potato Res 60:383. https://doi.org/10.1007/s11540-018-9384-1

Birch PRJ, Bryan GJ, Fenton B, Gilroy EM, Hein I, Jones JT, Prashar A, Taylor MA, Torrance L, Toth IK (2012) Crops that feed the world 8: potato: are the trends of increased global production sustainable? Food Secur 4:477-508. https://doi.org/10.1007/s12571-012-0220-1

Black RE, Victora CG, Walker SP, Bhutta ZA, Christian P, de Onis M, Ezzati M, GranthamMcGregor S, Katz J, Martorell R, Uauy R (2013) Maternal and child undernutrition and overweight in low-income and middle-income countries. Lancet 832(9890):427-451

Bohl WH, Johnson SB (2010) Commercial potato production in North America. The Potato Association of America Handbook. http://potatoassociation.org/wp-content/ uploads/2014/04/A_ProductionHandbook_Final_000.pdf

Borch D, Juul-Hindsgaul N, Veller M, Astrup A, Jaskolowski J, Raben A (2016) Potatoes and risk of obesity, type 2 diabetes, and cardiovascular disease in apparently healthy adults: a systematic review of clinical intervention and observational studies. Am J Clin Nutr 104(2):489-498

Burlingame B, Mouillé B, Charrondiére UR (2009) Review: nutrients, bioactive non-nutrients and anti-nutrients in potatoes. J Food Compos Anal 22:494-502

CGIAR Research Program on Roots, Tubers and Bananas (2016) Multi-stakeholder framework for intervening in RTB seed systems: user's guide. Lima (Peru), 13 p. RTB Working Paper. ISSN 2309-6586, no. 2016-1

Creed-Kanashiro H, Hareau G, Devaux A, Maldonado L, Ordinola M, Fonseca C, Suarez V, Astete L, Marin M, Penny M (2015) Agriculture-nutrition linkages: analyzing nutritional outcomes of interventions in potato-based production systems of Peru. In: 2nd international conference on global food security, October 11-14, 2015. Cornell University, Ithaca

Crowder DW et al (2010) Organic agriculture promotes evenness and natural pest control. Nature 466:109-112

DeFauw Sherri L, He Z, Larkin RP, Mansour SA (2012) Sustainable potato production and global food security. In: He Z, Larkin R, Honeycutt W (eds) Sustainable potato production: global case studies. Springer, Amsterdam, $531 \mathrm{pp}$ 
Delgado L, Schuster M, Torero M (2017) The reality of food losses: a new measurement methodology. IFPRI discussion paper 1686. International Food Policy Research Institute (IFPRI), Washington, DC. http://ebrary.ifpri.org/cdm/ref/collection/p15738coll2/id/131530

Devaux A, Torero M, Donovan J, Horton DE (eds) (2016) Innovation for inclusive value-chain development: successes and challenges. International Food Policy Research Institute (IFPRI), Washington, DC. https://doi.org/10.2499/9780896292130

Devaux A, Goffart JP, Kromann P, Toth I, Braguard C, Declerck S (2017) Report on CIP-EAPR Workshop 2017 on biocontrol and biostimulant agents for the potato crop. Potato Res 60:291. https://doi.org/10.1007/s11540-018-9385-0

Devaux A, Torero M, Donovan J, Horton D (2018) Agricultural innovation and inclusive valuechain development: a review. J Agribus Dev Emerg Econ 8(1):99-123. https://doi.org/10.1108/ JADEE-06-2017-0065

Douches DS, Maas D, Jastrzebski K, Chase RW (1996) Assessment of potato breeding progress in the USA over the last century. Crop Sci 36(6):1544-1552

Durroux-Malpartida V (2014) EAPR and CIP strengthen collaboration to tap potatoes' potential. Potato Res 57:367. https://doi.org/10.1007/s11540-014-9276-y

European Commission (2007). The potato sector in the European Union. Commission staff working document. SEC(2007) 533

Eurostat (2017) The EU potato sector—statistics on production, prices and trade. http://ec.europa. eu/eurostat/statistics-explained/index.php/The_EU_potato_sector_-_statistics_on_production ,_prices_and_trade\#Publications

Fajardo J, Lutaladio N, Larinde M, Rosell C, Barker I, Roca W et al (2010) Quality declared planting material: protocols and standards for vegetatively propagated crops: expert consultation, Lima, 27-29 November 2007. Food and Agriculture Organization of the United Nations, Rome

FAO (2002) The state of food insecurity in the world 2001, Rome, pp 4-7

FAO (2006a) Food security. Policy brief. FAO, Rome

FAO (2006b) Quality declared seed system. FAO plant protection and protection paper \# 185, Rome

FAO (2009) International year of the potato 2008: new light on a hidden treasure. http://www.fao. org/potato-2008/en/events/book.html

FAO (2014) FAO statistical databases FAOSTAT. http://faostat3.fao.org/

FAO (2016) FAOSTAT Database. http://www.fao.org/faostat/en/\#data/QC

FAO (2015a) Household seed security concepts and indicators. Discussion paper, $10 \mathrm{pp}$

FAO (2015b) FAOSTAT database. http://www.fao.org/faostat/en/\#data/FBS

FAO (2016) Seed security assessment: a practitioner's guide, Rome

FAO, IFAD, UNICEF, WFP and WHO (2018) The state of food security and nutrition in the world 2018. Building climate resilience for food security and nutrition. FAO, Rome

FAOSTAT (2013) Food balance sheet. http://www.fao.org/faostat/en/\#data/FBS

FAOSTAT (2017) Food and agriculture data. http://www.fao.org/faostat/en/\#data/QCinfo

Foley JA et al (2011) Solution for a cultivated planet. Nature 478:337-342

Gatto M, Hareau G, Pradel W, Suarez V, Qin J (2018) Release and adoption of improved potato varieties in Southeast and South Asia. International Potato Center (CIP), Lima, Peru, 42 p. Social sciences working paper no. 2018-2. ISBN 978-92-9060-501-0

Gildemacher PR, Kaguongo W, Ortiz O, Tesfaye A, Woldegiorgis G, Wagoire WW, Kakuhenzire R, Kinyae P, Nyongesa M, Struik PC, Leeuwis C (2009) Improving potato production in Kenya, Uganda and Ethiopia: a system diagnosis. Potato Res 52(2):173-205

Gildemacher PR, Schulte-Geldermann E, Borus D, Demo P, Kinyae P, Mundia P et al (2011) Seed potato quality improvement through positive selection by smallholder farmers in Kenya. Potato Res 54:253-266

Gillespie S, Van den Bold M (2017) Agriculture, food systems, and nutrition: meeting the challenge. Global Chall 1:1600002. https://doi.org/10.1002/gch2.201600002

Goffart JP, Olivier M, Frankinet M (2008) Potato crop nitrogen status assessment to improve N fertilization management and efficiency: past-present-future. Potato Res 51(3):355-383. https:// doi.org/10.1007/s11540-008-9118-x 
Goffart JP, Gobin A, Delloye C, Curnel Y (2017) Crop spectral reflectance to support decision making on crop nutrition. Paper presented to the International Fertiliser Society at a conference in Cambridge, United Kingdom, on 7th December 2017. Proceedings 812, pp. 29. www. fertiliser-society.org ( 2017 International Fertiliser Society-ISBN 978-0-85310-449-0

Haggblade S, Hazell PBR, Reardon T (2007) Research perspectives and prospectives on the rural nonfarm economy. In: Haggblade S, Hazell PBR, Reardon T (eds) Transforming the rural nonfarm sector: opportunities and threats in the developing world. The Johns Hopkins University Press, Baltimore

Hall A, Bockett G, Taylor S, Sivamohan MVK, Clark N (2001) Why research partnerships really matter: innovation theory, institutional arrangements and implications for developing new technology for the poor. World Dev 29(5):783-797

Harahagazwe D, Condori B, Barreda C, Bararyenya A, Byarugaba AA, Kude DA, Lung'aho C, Martinho C, Mbiri D, Nasona B, Ochieng B, Onditi J, Randrianaivoarivony JM, Tankou CM, Worku A, Schulte-Geldermann E, Mares V (CIP), de Mendiburu F, Quiroz R (CIP) (2018) How big is the potato (Solanum tuberosum L.) yield gap in Sub-Saharan Africa and why? A participatory approach. Open Agric 3(2):180-189. ISSN 2391-9531 .

Hareau G, Kleinwechter U, Pradel W, Suarez V, Okello J, Vikraman S (2014) Strategic assessment of research priorities for Potato. Lima (Peru). CGIAR Research Program on Roots, Tubers and Bananas (RTB). RTB working paper 2014-8. www.rtb.cgiar.org

Haverkort AJ, Struik PC (2015) Yield levels of potato crops: recent achievements and future prospects. Field Corp Res 182:76-85

Haverkort A, de Ruijter FJ, van Evert FK, Conijn JG, Rutgers B (2014) Worldwide sustainability hotspots in potato cultivation. 1. Identification and mapping. Potato Res 56:343-353

Hazell P, Haggblade S (1989) Agricultural technology and farm-nonfarm growth linkages. Agric Econ 3:345-364

Headey DD, Jayne TS (2014) Adaptation to land constraints: is Africa different? Food Policy 48:18-33

INEI Peru (2017) IV Censo Nacional Agropecuario (CENAGRO). Lima. INEI Perú (2017). Encuesta demográfica y de salud familiar 2016. Lima, Peru

Jayne TS, Chamberlin J, Headey DD (2014) Land pressures, the evolution of farming systems, and development strategies in Africa: a synthesis. Food Policy 48:1-17

Kanter R, Walls HL, Tak M, Roberts F, Waage J (2015) A conceptual framework for understanding the impacts of agriculture and food system policies on nutrition and health. Food Secur 7(4):767-777

Kleinwechter U, Hareau G, Suarez V (2014) Prioritization of options for potato research for development - results from a global expert survey. Lima (Peru). CGIAR Research Program on Roots, Tubers and Bananas (RTB). RTB working paper 2014-7. www.rtb.cgiar.org

Kunkel R, Campbell GS (1987) Maximum potential potato yield in the Columbia Basin, USA: model and measured values. Am Potato J 64(7):355

Labarta R (2015) The effectiveness of potato and sweetpotato improvement programmes from the perspectives of varietal output and adoption in Sub-Saharan Africa. In: Walker T, Alwang $\mathrm{J}$ (eds) Crop improvement, adoption, and impact of improved varieties in food crops in SubSaharan Africa. CABI, Wallingford

Muthoni J, Mbiyu MW, Nyamongo DO (2010) A review of potato seed systems and germplasm conservation in Kenya. J Agric Food Inform 11(2):157-167

Obura B, et al (2016) Cost benefit analysis of seed potato replacement strategies among smallholder farmers in Kenya. Tropentag, September 18-21, 2016, Vienna, Austria. http://www. tropentag.de/2016/abstracts/links/Obura_eAhVYqsS.pdf. Accessed 7 Sept 2018

Olsen N (2014) Potato storage management: a global perspective. Potato Res 57:331-333. https:// doi.org/10.1007/s11540-015-9283-7

Pandey A (2015) Rural farm and non-farm linkages in Uttar Pradesh. J Land Rural Stud 3(2):203-218 
PGSC (The Potato Genome Sequencing Consortium) (2011) Genome sequence and analysis of the tuber crop potato. Nature 475:189-195

Pingali P (2006) Westernization of Asian diets and the transformation of food systems: implications for research and policy. Food Policy 32(3):281-298

Pinstrup-Andersen P (2014) Food systems and human nutrition: relationships and policy interventions. In: Thompson B, Amoroso L (eds) Improving diets and nutrition: food-based approaches (Chapter 2). CABI, Wallingford, pp 8-20

Quiroz R, Ramírez DA, Kroschel J, Andrade-Piedra J, Barreda C, Condori B et al (2018) Impact of climate change on the potato crop and biodiversity in its center of origin. Open Agric 3:273-283

Reardon T, Chen K, Minten B, Adriano L (2012) The quiet revolution in staple food value chains: enter the dragon, the elephant and the tiger. Asian Development Bank (ADB) and International Food Policy Research Institute (IFPRI), Mandaluyong City

Rosegrant MW, Sulser TB, Mason-D’Croz D, Cenacchi N, Nin-Pratt A, Dunston S, Zhu T, Ringler C, Wiebe K, Robinson S, Willenbockel D, Xie H, Kwon H-Y, Thomas TS, Wimmer F, Schaldach R, Nelson GC, Willaarts B (2017) Quantitative foresight modeling to inform the CGIAR research portfolio. Project report for USAID. International Food Policy Research Institute (IFPRI), Washington, DC

Salazar L, Aramburu J, González M, Winters P (2016) Food security and productivity: impacts of technology adoption in small subsistence farmers in Bolivia. Food Policy 65:32-52

Schulte-Geldermann E, Gildemacher PR, Struik PC (2012) Improving seed health and seed performance by positive selection in three Kenyan potato varieties. Am J Potato Res 89:429-437. https://link.springer.com/content/pdf/10.1007\%2Fs12230-012-9264-1.pdf. Accessed 13 Sept 2018

Scott G (2011) Growth rates for potatoes in Latin America in comparative perspective: 1961-07. Am J Potato Res 88:143-152

Scott GJ, Suarez V (2011) Growth rates for potato in India and their implications for industry. Potato J 38(2):100-112

Scott GJ, Suarez V (2012a) From Mao to McDonald's: emerging markets for potatoes and potato products in China 1961-2007. Am J Potato Res 89(3):216-231

Scott GJ, Suarez V (2012b) The rise of Asia as the center of global potato production and some implications for industry. Potato J 39(1):1-22

Scott GJ, Suarez V (2012c) Limits to growth or growth to the limits? Trends and projections for potatoes in China and their implications for industry. Potato Res 55(2):135-156

Smith A, Snapp S, Chikowoa R, Thorne P, Bekunda B, Gloverd J (2017) Measuring sustainable intensification in smallholder agroecosystems: a review. Glob Food Sec 12:127-138

The Wall Street Journal (2015) Pushing the potato: China wants people to eat more 'Earth Beans'. https://www.wsj.com/amp/articles/BL-CJB-25584? responsive=y

Thiele G, Hareau G, Suarez V, Chujoy E, Bonierbale M, Maldonado L (2008) Varietal change in potatoes in developing countries and the contribution of the International Potato Center: 1972-2007. International Potato Center (CIP), Lima, Peru. Working paper 2008-6, 46 p

Thomas-Sharma S, Abdurahman A, Ali S, Andrade-Piedra JL, Bao S, Charkowski AO et al (2015) Seed degeneration in potato: the need for an integrated seed health strategy to mitigate the problem in developing countries. Plant Pathol 65:3-16. https://www.researchgate.net/publication/280913576_Seed_degeneration_in_potato_The_need_for_an_integrated_seed_health_ strategy_to_mitigate_the_problem_in_developing_countries. Accessed 13 Sept 2018

Velivelli SLS, Sessitsch A, Prestwich BD (2014) The role of microbial inoculants in integrated crop management systems. Potato Res 57(3-4):291-309

Von Grebmer K et al (2017) Global hunger index: getting to zero hunger. Welthungerhilfe/ International Food Policy Research Institute/Concern Worldwide, Bonn/Washington, DC/ Dublin. https://doi.org/10.2499/9780896292710 
World Bank (2017) Gaining momentum in Peruvian agriculture: opportunities to increase productivity and enhance competitiveness. World Bank, Washington, DC

Wu W, Yu Q, You L, Chen K, Tang H, Liu J (2018) Global cropping intensity gaps: increasing food production without cropland expansion. Land Use Policy 76:515-525

You L, Wood-Sichra U, Fritz S, Guo Z, See L, Koo J (2014) Spatial Production Allocation Model (SPAM) 2005 v3.2. http://mapspam.info

Open Access This chapter is licensed under the terms of the Creative Commons Attribution 4.0 International License (http://creativecommons.org/licenses/by/4.0/), which permits use, sharing, adaptation, distribution and reproduction in any medium or format, as long as you give appropriate credit to the original author(s) and the source, provide a link to the Creative Commons license and indicate if changes were made.

The images or other third party material in this chapter are included in the chapter's Creative Commons license, unless indicated otherwise in a credit line to the material. If material is not included in the chapter's Creative Commons license and your intended use is not permitted by statutory regulation or exceeds the permitted use, you will need to obtain permission directly from the copyright holder.

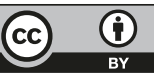

